\title{
Aluminum prevents stomatal conductance from responding to vapor pressure deficit in Citrus limonia
}

\author{
Giselle Schwab Silva ${ }^{a}$, Marina Alves Gavassi ${ }^{\mathrm{a}}$, Matheus Armelin Nogueira ${ }^{\mathrm{a}}$, \\ Gustavo Habermann ${ }^{\mathrm{b}, *}$ \\ a Programa de Pós-Graduação em Biologia Vegetal, Universidade Estadual Paulista (UNESP), Instituto de Biociências, Departamento de Botânica, Av. 24-A, 1515, Rio \\ Claro, SP, 13506-900, Brazil \\ ${ }^{\mathrm{b}}$ Universidade Estadual Paulista (UNESP), Instituto de Biociências, Departamento de Botânica, Av. 24-A, 1515, Rio Claro, SP, 13506-900, Brazil
}

\section{A R T I C L E IN F O}

\section{Keywords:}

Indirect $\mathrm{Al}$ effect

Leaf gas exchange

Leaf hydration

'Rangpur' lime

\begin{abstract}
A B S T R A C T
Stomatal aperture generally increases in response to low vapor pressure deficit (VPD) and decreases at high VPD. Aluminum (Al) inhibits root growth, indirectly exposing the roots to low water availability, which may decrease leaf hydration and, consequently, the stomatal conductance ( $g s$ ). In this study, Citrus limonia ('Rangpur' lime) was grown in nutrient solution with $1480 \mu \mathrm{M} \mathrm{Al}$ for 90 days, and we expected that the presence of $\mathrm{Al}$ could prevent $g s$ from responding to VPD. As expected, gs did not respond to the increase in VPD in plants exposed to Al. Aluminum also reduced the relative water content and midday leaf water potential ( $\Psi$ md) after 60 and 90 days. The $\mathrm{CO}_{2}$ assimilation rate $(A)$ followed the same response pattern exhibited by $g s$, the estimation of the carboxylation efficiency was not reduced in plants exposed to $\mathrm{Al}$ and measured under drier air, while photochemical responses were slightly reduced in plants exposed to $\mathrm{Al}$, indicating that the $\mathrm{Al}$-induced decrease in $A$ was dependent on gs and less ascribed to low photochemical performance. Like in drought conditions, the longterm exposure to $\mathrm{Al}$ reduces leaf hydration and compromises gs responses to the atmosphere, eventually impairing $A$ in 'Rangpur' lime plants.
\end{abstract}

\section{Introduction}

Stomatal aperture allows leaf $\mathrm{CO}_{2}$ assimilation while restricting water vapor loss to the atmosphere through transpiration. In well-hydrated plants, stomatal conductance ( $g s)$ exerts control over transpiration rate $(E)$ maintaining leaf at optimal temperature for photosynthesis and also preventing heat damage under excessive irradiance (Schulze, 1986; Chaves et al., 2016). Then, a well-hydrated mesophyll is critical for providing turgor pressure for stomatal movement and fully control of $E$.

Stomatal conductance varies continuously according to changes in the environment, such as atmospheric $\mathrm{CO}_{2}$ concentration, sunlight, air temperature, air relative humidity ( $\mathrm{RH}$ ), wind, etc (Farquhar and Sharkey, 1982; Chaves et al., 2016). Soil water content directly affects leaf hydration, so that low soil water potential $\left(\Psi_{\text {soil }}\right)$, under drought conditions for example, may reflect in low leaf hydration and, consequently, low gs (Schulze, 1986; Chaves et al., 2002). In addition, water reaches the mesophyll coming from the roots to replace water lost to the atmosphere that, depending on air temperature and $\mathrm{RH}$, may have different vapor pressure deficits (VPD). VPD also influences gs, so that stomatal aperture decreases when exposed to drier air (high VPD) and increases at high air humidity (low VPD) for a wide range of species (Lange et al., 1971; Habermann et al., 2003; McAdam and Brodribb, 2015). Although the mechanisms for these responses are not well known, it is believed that stomata may passively close due to a low water content in the mesophyll possibly induced by the evaporative demand (Lange et al., 1971; Mott and Peak, 2013); another hypothesis involves the abscisic acid (ABA) (Xie et al., 2006; Bauer et al., 2013), a plant hormone known to cause stomatal closure (Kriedemann et al., 1972; Merilo et al., 2015). Therefore, any factor affecting the leaf hydration may also influence $g s$, which in turn may stop responding to the VPD.

Among environmental factors, drought is directly associated with low gs (Farquhar and Sharkey, 1982; Chaves et al., 2002), and drought may induce root growth so as to reach water in deep soil layers (Sharp et al., 2004; Yang et al., 2013). In contrast to drought, aluminum (Al) decreases root growth and development (Horst et al., 2010; Yang et al., 2013), indirectly exposing the roots to low water availability. Aluminum is the third most abundant element in the Earth's crust and in acidic soils $(\mathrm{pH}<5.0)$, which composes $30-45 \%$ of the world's ice-

\footnotetext{
* Corresponding author.

E-mail address: ghaber@rc.unesp.br (G. Habermann).
} 
free land (von Uexküll and Mutert, 1995) it is hydrolysed to its phytotoxic form $\left(\mathrm{Al}^{3+}\right)$. Mostly retained in the roots (Vitorello et al., 2005; Horst et al., 2010), Al binds to the pectic net in the apoplast of root cells (Kopittke et al., 2015), primarily stunting the root growth. This is similar to what heavy metals (HM) cause in plants (He et al., 2015; Luo et al., 2016), although $\mathrm{Al}$ is not considered a HM. Despite causing direct effects on the root system, $\mathrm{Al}$ also causes $40 \%$ lower $\mathrm{CO}_{2}$ assimilation rate $(A)$ in 'Cleopatra' tangerine (Citrus reshni Hort. ex. Tanaka) (Chen et al., 2005), 50\% lower $A$ in coffee plants (Coffea arabica) (Konrad et al., 2005), and 60-70\% lower $A$ in Citrus grandis (Jiang et al., 2008, 2009). These studies attribute the Al-induced decrease in $A$ to low photochemical performance rather than low $g s$. However, in these same studies gs was also significantly reduced in the presence of Al. In addition, for 'Rangpur' lime plants (Citrus limonia), Al-induced decrease in $A$ is better explained by the low $g s$ rather than low photochemical responses (Banhos et al., 2016). These authors have evidenced fibrous xylem vessels in the stele associated with low water uptake/transport causing low $g s$ and leaf hydration. Al-induced decrease in water transport was also evidenced in barley (Ahmed et al., 2016). Then, as plants exposed to $\mathrm{Al}$ develop still unknown mechanisms that decrease water uptake, $\mathrm{Al}$ is associated with low leaf hydration and it could prevent $g s$ from responding to VPD.

Here we chose 'Rangpur' lime plants to test the hypothesis that the presence of $\mathrm{Al}$ in nutrient solution prevents gs from responding to VPD. 'Rangpur' lime is an important rootstock largely used in rain-fed Citrus plantations that are usually grown on acidic soils rich in $\mathrm{Al}$ in subtropical areas of the Americas, due to its high drought resistance (Magalhães Filho et al., 2008). In this region, the soil is usually acidic and rich in Al (von Uexküll and Mutert, 1995) and Citrus groves strongly depend on yearly lime application to the soil. Therefore, Al could cause a great impact on its water relations and implications to leaf gas exchange and plant growth. To test this hypothesis, we measured leaf gas exchange rates, including $g s$, and photochemical parameters measured at 1.5 and $2.5 \mathrm{kPa}$ of VPD, as well as leaf relative water content, predawn and midday leaf water potential and plant biomass in a 90-day study exposing plants to 0 and $1480 \mu \mathrm{M} \mathrm{Al}$.

\section{Material and methods}

\subsection{Plant material and experimental conditions}

We used three-month-old and $15 \pm 0.5 \mathrm{~cm}$-high 'Rangpur' lime plants (Citrus limonia) that were obtained from a commercial Citrus nursery (Sanicitrus, Araras, SP, Brazil). After rinsing the roots of these plants under tap water, the plants were transferred to a hydroponic system (aerated solution) and grew directly on a nutrient solution inside opaque plastic boxes $(50 \mathrm{~cm}$ in length $\times 30 \mathrm{~cm}$ in width $\times 15 \mathrm{~cm}$ in height; $20 \mathrm{~L}$ ) for 90 days.

The nutrient solution showed a chemical composition based on the solution proposed by Clark (1975), and it has been already used to test $\mathrm{Al}$ resistance in 'Rangpur' lime plants (Banhos et al., 2016). It consisted of $1372.8 \mu \mathrm{M} \mathrm{Ca}\left(\mathrm{NO}_{3}\right)_{2} 4 \mathrm{H}_{2} \mathrm{O}, 507 \mu \mathrm{M} \mathrm{NH} \mathrm{NO}_{3}, 224.4 \mu \mathrm{M} \mathrm{KCl}, 227.2$ $\mu \mathrm{M} \mathrm{K} \mathrm{SO}_{4}, 218.6 \mu \mathrm{M} \mathrm{KNO} 3,483.2 \mu \mathrm{M} \mathrm{Mg}\left(\mathrm{NO}_{3}\right)_{2} 6 \mathrm{H}_{2} \mathrm{O}, 12.9 \mu \mathrm{M}$ $\mathrm{KH}_{2} \mathrm{PO}_{4}, 26.01 \mu \mathrm{M} \mathrm{FeSO}{ }_{4} 7 \mathrm{H}_{2} \mathrm{O}, 23.8 \mu \mathrm{M}$ NaEDTA, $3.5 \mu \mathrm{M} \mathrm{MnCl}_{2}$ $4 \mathrm{H}_{2} \mathrm{O}, 9.9 \mu \mathrm{M} \mathrm{H}_{3} \mathrm{BO}_{3}, 0.9 \mu \mathrm{MnSO}_{4} 7 \mathrm{H}_{2} \mathrm{O}, 0.2 \mu \mathrm{M} \mathrm{CuSO}_{4} 5 \mathrm{H}_{2} \mathrm{O}$, and $0.4 \mu \mathrm{M} \mathrm{NaMoO}{ }_{2} 2 \mathrm{H}_{2} \mathrm{O}$. In a previous study (Banhos et al., 2016), we observed that $1480 \mu \mathrm{M} \mathrm{Al}$ causes Al-induced decrease in gas exchange rates in 'Rangpur' lime plants after 45 days. Then, the solution contained 0 and $1480 \mu \mathrm{M} \mathrm{Al}$ provided through $1479.5 \mu \mathrm{M} \mathrm{AlCl}_{3} 6 \mathrm{H}_{2} \mathrm{O}$. The $\mathrm{pH}$ of the solution was monitored daily and maintained at $4.0 \pm 0.1$ to keep $\mathrm{Al}$ as soluble as possible, and the solution was totally replaced every 15 days (Banhos et al., 2016). The nominal chemical composition of this solution was also tested on Geochem-EZ software (Shaff et al., 2010), resulting in more than $85 \%$ free $^{\mathrm{Al}^{3+}}$ available. Samples of the nutrient solution were also collected $(n=3)$ every 15 days and sent to a routine plant nutrition lab at University of São Paulo (USP, Esalq,
Piracicaba), where $\mathrm{Al}$ was measured in the solution samples using the colorimetric method (Sarruge and Haag, 1974), and nominal $1480 \mu \mathrm{M}$ $\mathrm{Al}$ resulted in $1064 \pm 26 \mu \mathrm{M} \mathrm{Al}$.

Expanded polystyrene (Isopor $\left.{ }^{\circledR}\right) 50 \times 30 \mathrm{~cm}$ plates (2-cm thick), with six equidistant holes $(2.5 \mathrm{~cm}$ in diameter) each, were floated on the nutrient solution in the boxes, and the plants were fixed in these holes with polyurethane foam strips that were placed around the plant collar. The boxes were kept on benches, maintained inside a greenhouse, under semi-controlled conditions $(891.7 \pm 167.4 \mu \mathrm{mol}$ photons $\mathrm{m}^{-2} \mathrm{~s}^{-1}$; approximately $14 \mathrm{~h}$ of natural photoperiod). Mean air temperature and vapor pressure deficit (VPD) were measured between 9:00 and $11: 30 \mathrm{~h}$ (to follow the same daily time course used for measuring leaf gas exchange and chlorophyll fluorescence), using an aspirated psychrometer (ModelSK-RHG, Sato, Tokyo, Japan), and these values were $24.2 \pm 0.7^{\circ} \mathrm{C}$ and $1.64 \pm 0.39 \mathrm{kPa}$, respectively.

\subsection{Experimental design}

In plants cultivated in nutrient solution with 0 and $1480 \mu \mathrm{M} \mathrm{Al}$, we measured leaf gas exchange and chlorophyll fluorescence under 1.5 and $2.5 \mathrm{kPa}$ of VPD inside the leaf cuvette of a gas exchange system, at 1, 7, $15,30,45,60$ and 90 days after planting (DAP). On these same evaluation dates, we used leaves to measure the relative water content (RWC) and water potential at predawn ( $\Psi$ pd) and midday ( $\Psi \mathrm{md})$. At the beginning (0 DAP) and the end of the study (90 DAP), we measured the number of leaves, total leaf area, shoot length, root length, biomass of root, shoot, leaves, and total biomass, as well as $\mathrm{Al}$ content in roots, shoots and leaves. In addition, at $90 \mathrm{DAP}, \mathrm{A} / \mathrm{Ci}$ curves were assessed in leaves of plants exposed and not exposed to $\mathrm{Al}$ measured at 1.5 and $2.5 \mathrm{kPa}$ in order to estimate the apparent carboxylation efficiency.

\subsection{Photosynthetic parameters}

$\mathrm{CO}_{2}$ assimilation $(A)$ and transpiration $(E)$ rates, stomatal conductance $(g s)$, and intercellular $\mathrm{CO}_{2}(\mathrm{Ci})$ were measured with an open portable gas exchange system (LI-6400xt, LI-COR, Lincoln, NE, USA). The water use efficiency (WUE; $A / E$ ) and intrinsic water use efficiency (IWUE; $A / g s$ ) were also calculated. The $\mathrm{CO}_{2}$ concentration entering the leaf cuvette (LCF chamber; $2 \mathrm{~cm}^{2}$, LI-COR) averaged $400 \mu \mathrm{mol} \mathrm{mol}{ }^{-1}$, as provided by the $6400-01 \mathrm{CO}_{2}$ mixer (LI-COR). Measurements were taken between 9:00 and 11:30 h (Banhos et al., 2016) on cloudless days. The photosynthetic photon flux density (PPFD) was provided by an artificial light source (6400-40 LCF, LI-COR), which was set to provide $1500 \mu \mathrm{mol}$ photons $\mathrm{m}^{-2} \mathrm{~s}^{-1}$ in the leaf cuvette, as this value saturates $A$ for Citrus limonia as observed in $\mathrm{A} / \mathrm{Ci}$ curves (see below), and as also evidenced by Banhos et al. (2016).

The incoming air $\left(500 \mu \mathrm{mol} \mathrm{s}^{-1}\right)$ to the LI-6400xt was provided by a dew point generator (LI-610, LI-COR), which had a known temperature and $100 \%$ relative humidity. The air temperature in the leaf cuvette was the same of that in the external ambient (greenhouse), and with these values and based on psychometric equations it was possible to calculate and set the air temperature produced by the dew point generator, so that 1.5 and $2.5 \mathrm{kPa}$ of VPD was reached inside the leaf cuvette, according to Habermann et al. (2003).

Chlorophyll $a$ fluorescence was measured with a portable modulated fluorometer (6400-40 LCF, LI-COR), which was integrated into the LI-6400xt gas exchange system. The saturating light pulse was approximately $7000 \mu \mathrm{mol} \mathrm{m}^{-2} \mathrm{~s}^{-1}$ during $0.7 \mathrm{~s}$. The light fraction used for photosystem II (PSII) in photochemistry $\left[\mathbf{P}=\left(\left(\mathrm{F}_{\mathrm{m}}-\mathrm{F}_{\mathrm{s}}\right) / \mathrm{F}_{\mathrm{m}}{ }_{\mathrm{m}}\right)\right]$, heat dissipation in the antenna $\left[\mathbf{D}=1-\left(\mathrm{F}_{\mathrm{v}} / \mathrm{F}_{\mathrm{m}}{ }_{\mathrm{m}}\right)\right]$ and heat dissipation in reaction centers $\left[\mathrm{E}=(1-\mathrm{qP})\left(\mathrm{F}_{\mathrm{v}}{ }^{\prime} / \mathrm{F}_{\mathrm{m}}^{\prime}\right)\right]$ was calculated according to Demming-Adams (1996). For these calculations, $F^{\prime}{ }_{v}$ is the variable fluorescence between the maximal $\left(F_{m}{ }_{m}\right)$ and minimal $\left(F_{o}^{\prime}\right)$ fluorescence from light-adapted leaf and $\mathrm{F}_{\mathrm{s}}$ is the steady state fluorescence from light-adapted leaf. The photochemical quenching (qP) was calculated as $\left[q \mathrm{P}=\left(\mathrm{F}_{\mathrm{m}}^{\prime}-\mathrm{F}_{\mathrm{s}}\right) /\left(\mathrm{F}_{\mathrm{m}}-\mathrm{F}_{\mathrm{o}}{ }_{\mathrm{o}}\right)\right]$, according to Baker (2008). The effective 


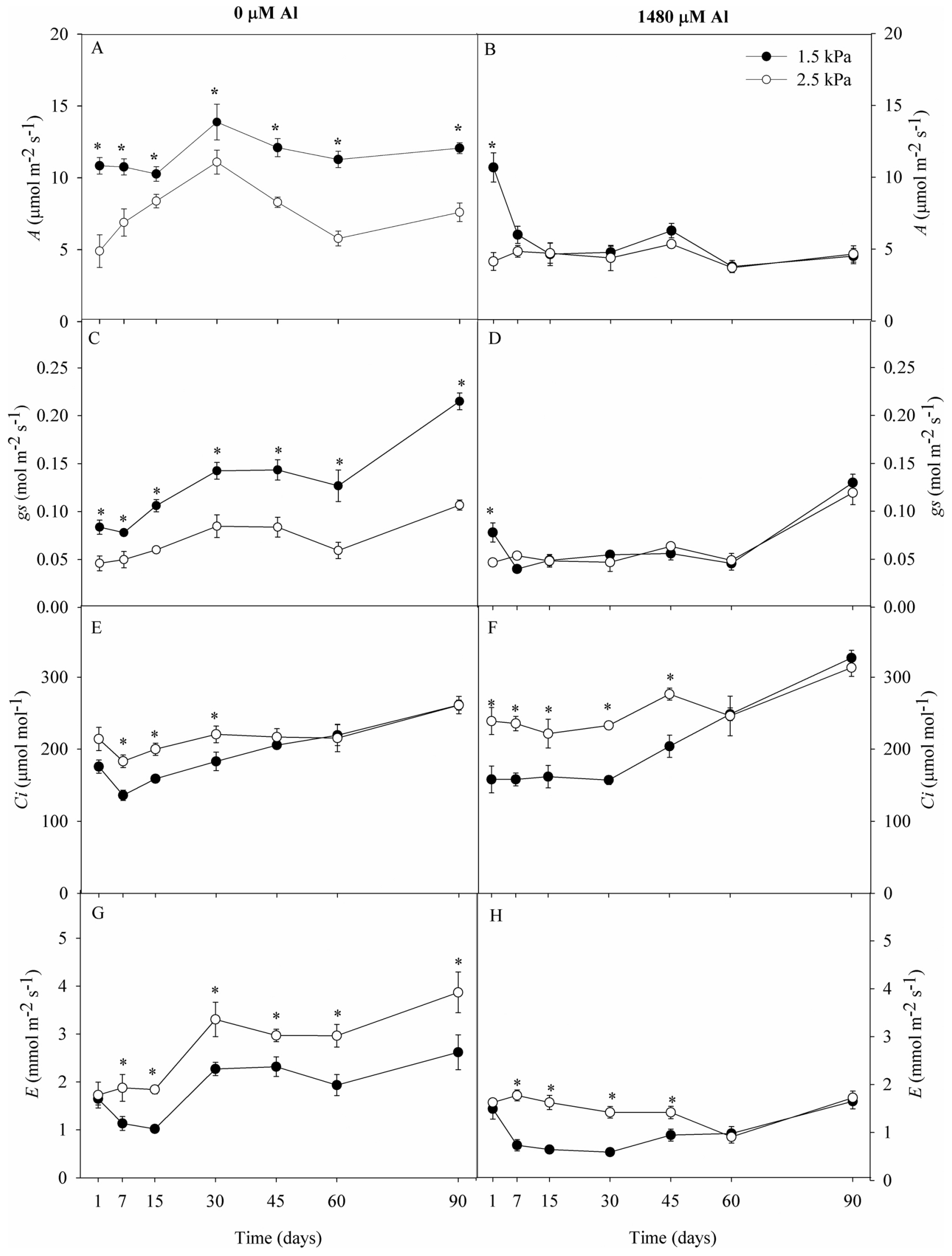

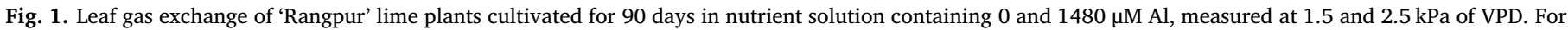

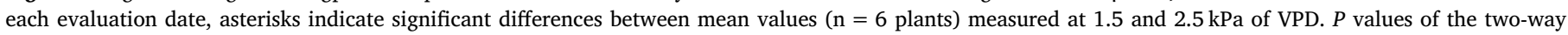
(ANOVA) for Al, VPD and their interaction (Al x VPD) are shown in Table S1 (Supplementary material). Bars are s.e. 
Table 1

Mean values $(n=6) \pm$ s.e. of the angular coefficient obtained from A/Ci curves to estimate the carboxylation efficiency of 'Rangpur' lime plants at 90 days after planting in nutrient solution containing 0 and $1480 \mu \mathrm{M} \mathrm{Al}$, measured at 1.5 and $2.5 \mathrm{kPa}$ of vapor pressure deficit.

\begin{tabular}{llll}
\hline Treatments & & & Estimation of carboxylation efficiency \\
$0 \mu \mathrm{M} \mathrm{Al}$ & $1.5 \mathrm{kPa}$ & & $0.0425 \pm 0.0061 \mathrm{a}$ \\
& $2.5 \mathrm{kPa}$ & & $0.0316 \pm 0.0038 \mathrm{ab}$ \\
$1480 \mu \mathrm{M} \mathrm{Al}$ & $1.5 \mathrm{kPa}$ & & $0.0282 \pm 0.0014 \mathrm{~b}$ \\
& $2.5 \mathrm{kPa}$ & & $0.0198 \pm 0.0010 \mathrm{~b}$
\end{tabular}

Different letters indicate significant differences by the Tukey test $(P<0.05)$ between treatments.

quantum yield of PSII [ФPSII $=\left(F_{m}^{\prime}-F s\right) / F_{m}^{\prime}$ ], and the apparent electron transport rate $[\mathrm{ETR}=\Phi \mathrm{PSII} \times \mathrm{PPFD} \times 0.5 \times 0.84]$ were also calculated.

A/Ci curves were performed under $1500 \mu \mathrm{mol}$ photons $\mathrm{m}^{-2} \mathrm{~s}^{-1}$ and $25^{\circ} \mathrm{C}$, at 1.5 and $2.5 \mathrm{kPa}$ in the leaf cuvette. The $\mathrm{CO}_{2}$ concentrations inside the leaf chamber (reference chamber) were set in the following sequence to compose the $A / C i$ curves: $400,300,200,100,50,25,400$, $600,800,1000$ and $1200 \mu \mathrm{mol} \mathrm{CO} \mathrm{mol}^{-1}$ air, according to Kissmann et al (2014).

\subsection{Leaf water potential and relative water content}

Leaf water potential was measured using four leaves per replicate (plant) at predawn $\left(\Psi_{\mathrm{pd}}\right)$ and midday ( $\Psi_{\mathrm{md}}$; under maximum VPD), and values in MPa were obtained by the pressure chamber method (Turner, 1981), using a DIK-7000 (Daiki Rika Kogyo, Tokyo, Japan) chamber.

The relative leaf water content (RWC) was assessed using six leaf discs per replicate (plant) in each treatment. It was calculated as RWC $(\%)=[(\mathrm{FW}-\mathrm{DW}) /(\mathrm{TW}-\mathrm{DW})] \times 100$, where $\mathrm{FW}$ is the fresh weight; TW is the turgid weight after rehydrating samples for $24 \mathrm{~h}$ in $100 \mathrm{~mL}$ deionized water; and DW is the dry weight after oven-drying the discs at $60{ }^{\circ} \mathrm{C}$ for $48 \mathrm{~h}$, according to Habermann et al. (2011).

\subsection{Biometric parameters}

After separating the plant parts into leaves (plus petioles), shoots and roots, the number of leaves was counted and the shoot and root lengths were measured with a ruler $(\mathrm{cm})$. The total leaf area per plant was measured with an area meter (LI-3100C, LI-COR). Leaf, shoot and root samples were oven-dried at $60^{\circ} \mathrm{C}$ until constant mass, and biomass (g) was measured using a scale.

\subsection{Aluminum concentration in plant organs}

Dried samples of leaves, shoots and roots were sent to a routine plant nutrition laboratory at University of São Paulo (Esalq, USP, Piracicaba) where these were ground and digested in a solution of sulfuric:nitric:percloric acids (1:10:2, v/v/v). After digestion, Al concentrations were determined by the atomic absorption spectrophotometer method (Sarruge and Haag, 1974) and expressed as mg Al per kg dry mass.

\subsection{Data analysis}

The study was conducted with six plants per treatment. A two-way analysis of variance (two-way ANOVA) was conducted using the VPD factor $(1.5$ and $2.5 \mathrm{kPa})$ and the $\mathrm{Al}$ factor $(0$ and $1480 \mu \mathrm{M} \mathrm{Al})$ in order to test $A, E, g s, C i$, WUE, IWUE, P, D, E, ФPSII, qP and ETR separately, on each evaluation date and the estimation of carboxylation efficiency (angular coefficient of $A / C i$ curves), at 90 DAP. A one-way ANOVA was performed between plants exposed to 0 and $1480 \mu \mathrm{M}$ Al to test differences in the number of leaves, total leaf area per plant, shoot length, root length, biomass of root, shoot, leaves, and total biomass as well as $\mathrm{Al}$ concentration in plant organs at 0 and 90 DAP. The Tukey test $(\mathrm{P}<0.05)$ was used to conduct post hoc comparisons to determine the least significant difference between mean results. In addition, a Student $t$-test $(\alpha=0.05)$ was used to test differences in RWC, $\Psi$ pd, $\Psi$ md on each evaluation date.

\section{Results}

\subsection{Photosynthetic parameters}

For these parameters, $P$ values of the two-way analysis of variance (ANOVA) as well as interactions between $\mathrm{Al}$ and VPD, for each evaluation date, are listed on Table S1 (Supplementary material). Leaf gas exchange rates, mainly $A$, gs and $E$ were reduced in plants exposed to $\mathrm{Al}$ at 7, 15, 30, 45, 60 and 90 DAP (Fig. 1; Table S1). In plants not exposed to $\mathrm{Al}$, as expected, $A$ and $g s$ decreased under $2.5 \mathrm{kPa}$ when compared with $1.5 \mathrm{kPa}$ (Fig. $1 \mathrm{~A}, \mathrm{C}$ ). The transpiration rate $(E)$, however, was higher at $2.5 \mathrm{kPa}$ in relation to $1.5 \mathrm{kPa}$ (Fig. $1 \mathrm{G}$ ), as well as $C i$ values that were higher at $2.5 \mathrm{kPa}$ at 7, 15 and $30 \mathrm{DAP}$ (Fig. 1E). In plants exposed to $\mathrm{Al}, g s$ and $A$ did not respond to the increase in VPD from 7 DAP until the end of the study (Fig. 1B, D). Transpiration rate and $\mathrm{Ci}$, however, were higher at $2.5 \mathrm{kPa}$ at 7, 15, 30 and $45 \mathrm{DAP}$ (Fig. $1 \mathrm{~F}, \mathrm{H}$ ).

At 90 DAP, $A_{\max }$ and the angular coefficient of $A / C i$ curves were higher in plants not exposed to $\mathrm{Al}$ in relation to those exposed to $\mathrm{Al}$ $(\mathrm{P}=0.004)$ (Table 1 ; Fig. 2). Only when measured at $1.5 \mathrm{kPa}$ was the angular coefficient of $\mathrm{A} / \mathrm{Ci}$ curves higher in plants not exposed to $\mathrm{Al}$ in relation to those exposed to $\mathrm{Al}$ (Table 1). In addition, as $\mathrm{Ci}$ is related to the estimation of the apparent carboxylation efficiency, it is important to note that, regardless of the VPD, this parameter was higher $(\mathrm{P}<0.05)$ in plants exposed to $\mathrm{Al}$ in relation to those not exposed to $\mathrm{Al}$, at $90 \mathrm{DAP}$ (Fig. 1E, F; Table S1).

Compared to plants not exposed to Al, regardless of the VPD, WUE was lower in plants exposed to $\mathrm{Al}$ at 15, 60, and 90 DAP (Fig. 3A, B; Table S1), and IWUE was also reduced in plants exposed to $\mathrm{Al}$ at 7,15 and 90 DAP (Fig. 3C, D; Table S1). Considering that $E$ responded to VPD in both $\mathrm{Al}$ treatments (Fig. 1G, H), WUE followed almost the same response pattern of leaf transpiration (Fig. 3A, B), while IWUE did not respond to VPD on most days for both $\mathrm{Al}$ treatments (Fig. 3C, D).

The fraction of absorbed light utilized in photochemistry (P) was lower in plants exposed to $\mathrm{Al}$ in relation to those not exposed to $\mathrm{Al}$, at 15, 30, 60 and 90 DAP. The heat dissipation in the antenna (D) increased in plants exposed to $\mathrm{Al}$ when compared to plants not exposed to $\mathrm{Al}$, at 15, 30, 45 and 60 DAP (Fig. 4; Table S1). In plants not exposed to $\mathrm{Al}, \mathbf{P}$ was similar (except at $60 \mathrm{DAP}$ ) between 1.5 and $2.5 \mathrm{kPa}$, while $\mathbf{D}$ increased with the enlargement of VPD (Fig. 4A, C; Table S1). However, in plants exposed to $\mathrm{Al}, \mathrm{P}$ was reduced at $2.5 \mathrm{kPa}$ in relation to $1.5 \mathrm{kPa}$ but only at 1, 7 and 60 DAP, and D increased under the highest VPD at 1 and 7 DAP (Fig. 4B, D; Table S1).

The values of $\Phi$ PSII and ETR were lower in plants exposed to Al when compared to those not exposed to $\mathrm{Al}$, at 7, 15, 30, 60 and $90 \mathrm{DAP}$, while the presence of $\mathrm{Al}$ reduced $\mathrm{qP}$ only at 15 and $30 \mathrm{DAP}$. In both Al treatments, ФPSII and ETR decreased at $2.5 \mathrm{kPa}$ only at 1 and $60 \mathrm{DAP}$, and $\mathrm{qP}$ was similar between both VPD throughout the study (Supplementary material; Table S1; Fig. S1).

\subsection{Leaf water potential and relative water content}

In relation to plants exposed to Al, the RWC of plants not exposed to $\mathrm{Al}$ was higher at $15 \mathrm{DAP}(+5 \%$; $\mathrm{P}=0.019), 30$ and $45 \mathrm{DAP}(+15 \%$; $\mathrm{P}=0.008$ and $\mathrm{P}<0.001$, respectively), and 60 and $90 \mathrm{DAP}(+20 \%$; $\mathrm{P}=0.002$ and $\mathrm{P}<0.001$, respectively) (Fig. 5). Predawn leaf water potential ( $\Psi$ pd) was the same between $\mathrm{Al}$ treatments throughout the study (Fig. 6A). Midday leaf water potential ( $\Psi \mathrm{md})$ of plants not exposed to $\mathrm{Al}$ was significantly higher than that of plants exposed to $\mathrm{Al}$ at $60(\mathrm{P}<0.001)$ and 90 DAP $(\mathrm{P}=0.029)$, although opposite results 


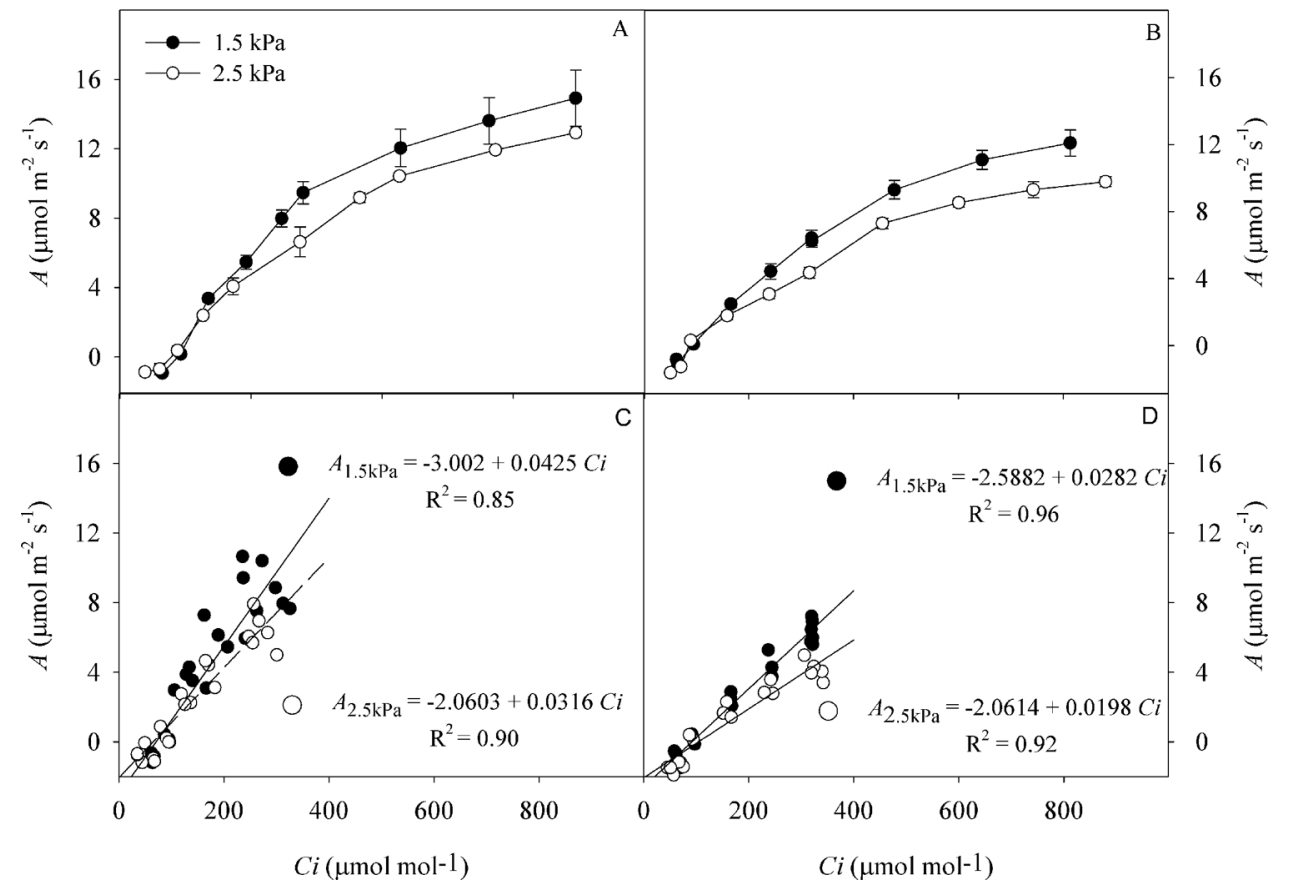

Fig. 2. $\mathrm{CO}_{2}$ assimilation rate $(A)$ in response to intercellular $\mathrm{CO}_{2}(\mathrm{Ci})(\mathrm{A} / \mathrm{Ci}$ curves $)(\mathrm{A}, \mathrm{C})$ and estimation of the apparent carboxylation efficiency from $\mathrm{A} / \mathrm{Ci}$ curves (B, D) of 'Rangpur' lime plants at 90 DAP cultivated in nutrient solution containing 0 and $1480 \mu \mathrm{M} \mathrm{Al}$ and measured at 1.5 and $2.5 \mathrm{kPa}$ of VPD. Bars are s.e.

occurred at $7(\mathrm{P}=0.029)$ and $45 \mathrm{DAP}(\mathrm{P}=0.017)$ (Fig. 6B).

\subsection{Biometric parameters}

The number of leaves ( $\mathrm{P}<0.001)$, total leaf area per plant $(\mathrm{P}=0.002)$, shoot length $(\mathrm{P}<0.001)$, root length $(\mathrm{P}<0.001)$, biomass of root $(\mathrm{P}<0.001)$, shoot $(\mathrm{P}=0.002)$, leaves $(\mathrm{P}<0.001)$, and total biomass $(\mathrm{P}<0.001)$ were higher in plants not exposed to $\mathrm{Al}$ in relation to those exposed to $\mathrm{Al}$ at $90 \mathrm{DAP}$ (Fig. 7). In plants exposed to $\mathrm{Al}$, shoot length was the only parameter that did not increase from 0 to
90 DAP $(P=0.148)$ (Fig. 7E).

\subsection{Aluminum concentration in plant organs}

At 90 DAP, $\mathrm{Al}$ accumulation was higher in the leaves $(\mathrm{P}=0.049)$ (Fig. 8A), shoots $(\mathrm{P}<0.001$ ) (Fig. 8B), roots $(\mathrm{P}<0.001$ ) (Fig. $8 \mathrm{C}$ ) and in the whole plant $(\mathrm{P}<0.001)$ (Fig. 8D) grown in nutrient solution with $\mathrm{Al}$ in relation to plants not exposed to $\mathrm{Al}$. However, the roots of plants exposed to $\mathrm{Al}$ accumulated 10 times more $\mathrm{Al}$ than those of plants not exposed to $\mathrm{Al}$ at 90 DAP (Fig. 8C).

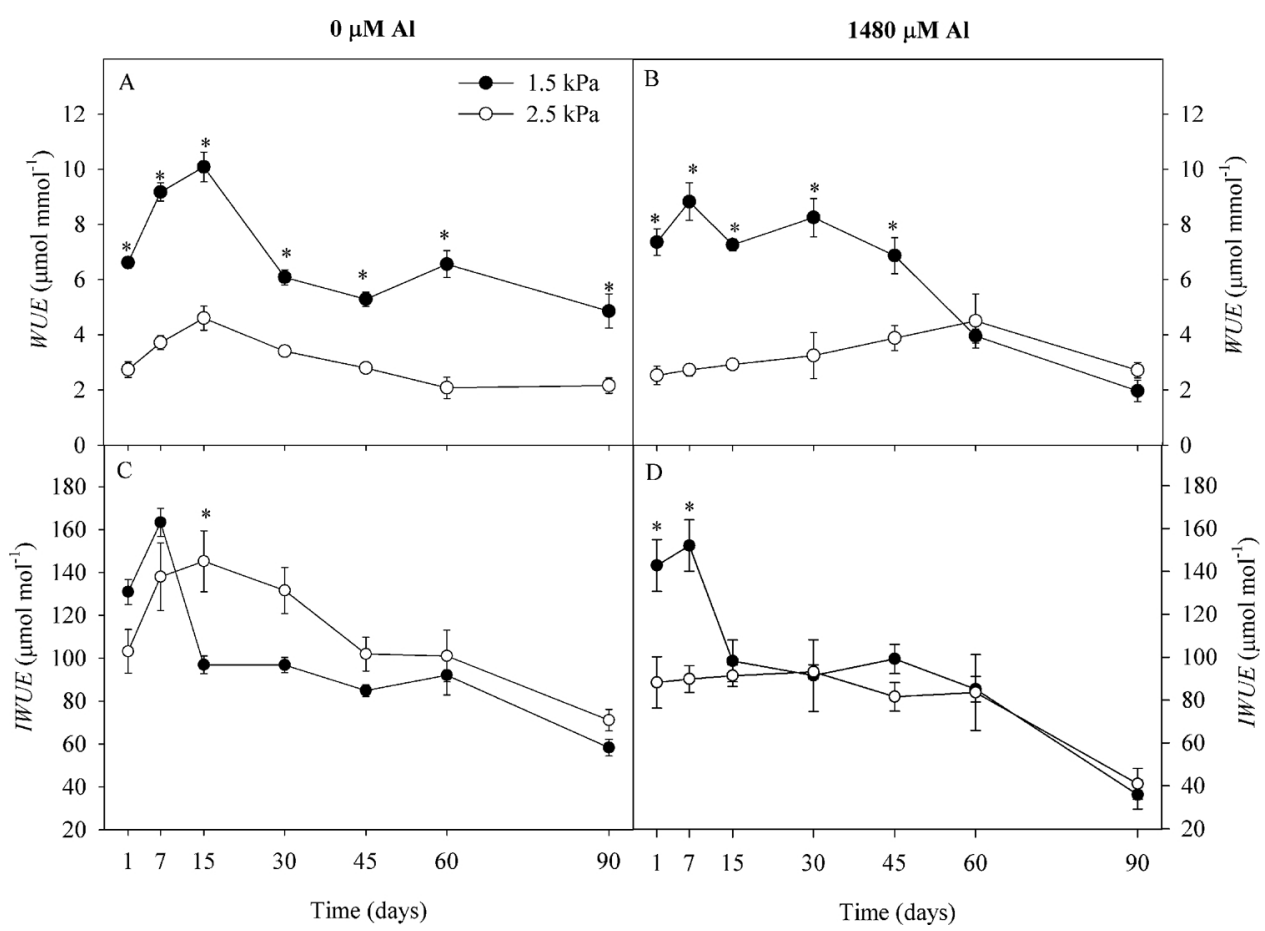

Fig. 3. Water use efficiency (WUE) and intrinsic water use efficiency (IWUE) of 'Rangpur' lime plants cultivated for 90 days in nutrient solution containing 0 and $1480 \mu \mathrm{M} \mathrm{Al}$ measured at 1.5 and $2.5 \mathrm{kPa}$ of VPD. For each evaluation date, asterisks indicate significant differences between mean values $(\mathrm{n}=6$ plants) measured at 1.5 and $2.5 \mathrm{kPa}$ of VPD. $P$ values of the two-way (ANOVA) for Al, VPD and their interaction (Al x VPD) are shown in Table S1 (Supplementary material). Bars are s.e. 


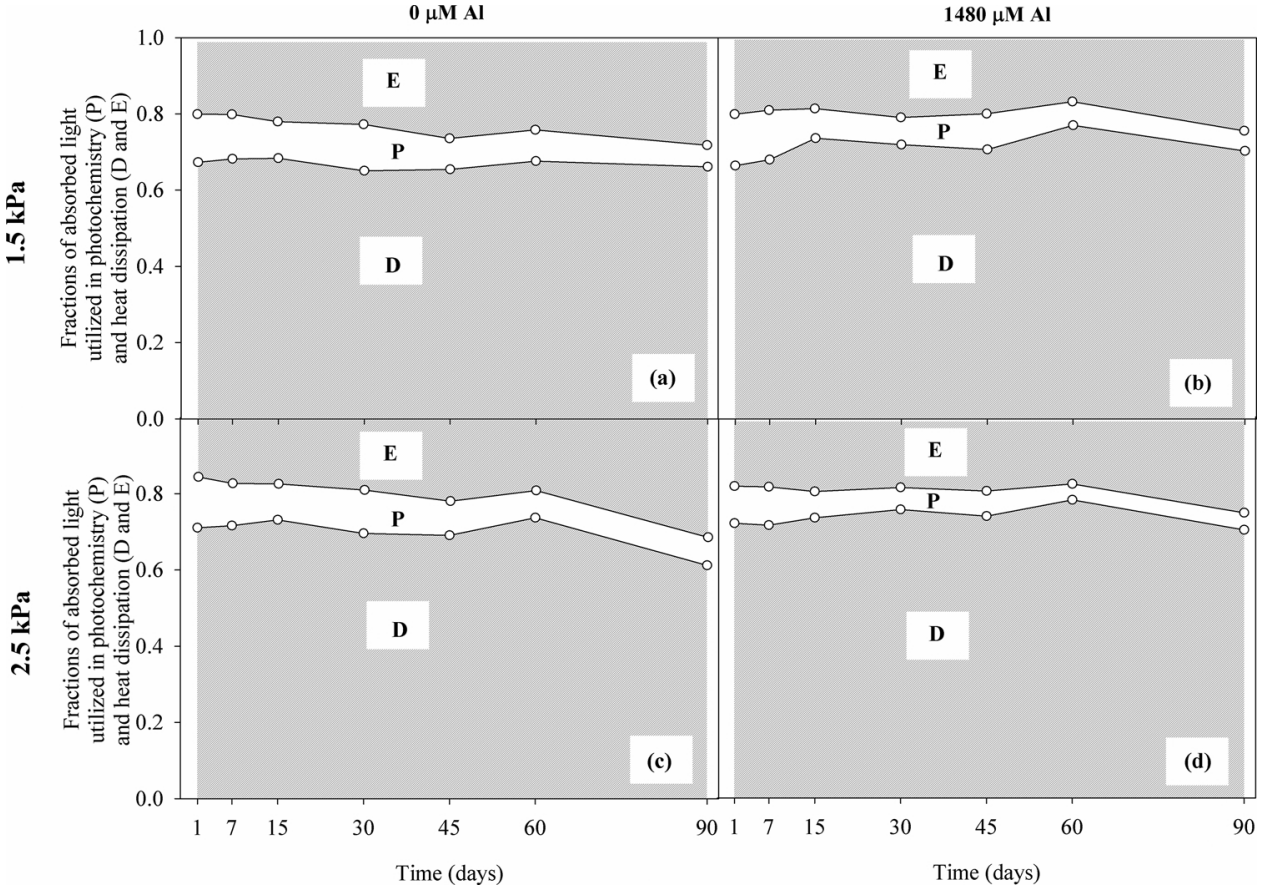

Fig. 4. Variations in fractions of absorbed light utilized in photochemistry (P), heat dissipation in the antenna (D) and in reaction centers (E) of PSII of 'Rangpur' lime plants cultivated for 90 days in nutrient solution containing 0 and $1480 \mu \mathrm{M} \mathrm{Al}$ measured at 1.5 (A, B) and $2.5 \mathrm{kPa}$ (C, D) of VPD. $P$ values of the two-way (ANOVA) for Al, VPD and their interaction (Al $\mathrm{x}$ VPD) are shown in Table S1 (Supplementary material).

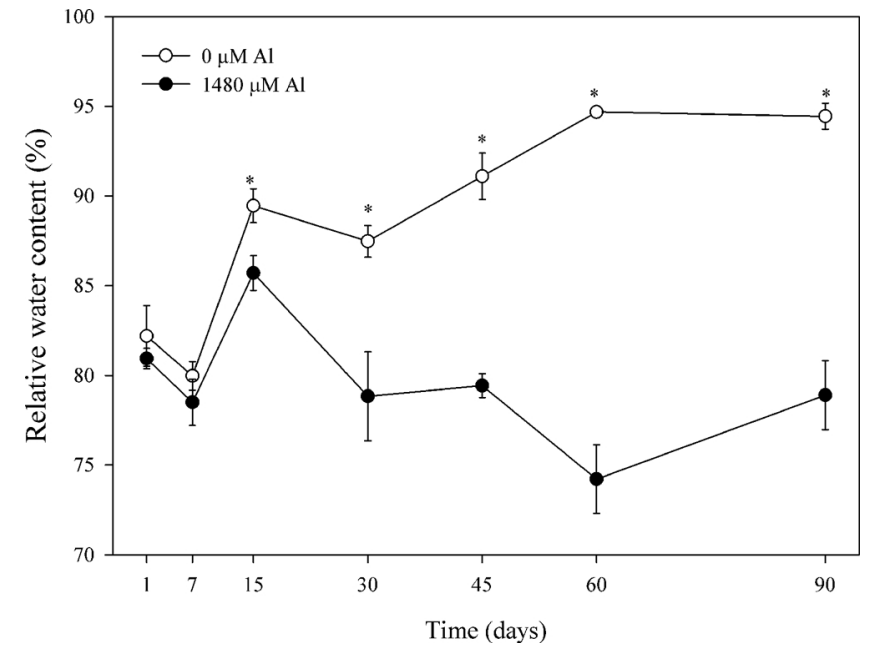

Fig. 5. Relative water content of 'Rangpur' lime plants cultivated for 90 days in nutrient solution containing 0 and $1480 \mu \mathrm{M}$ Al. For each evaluation date, asterisks indicate significant difference by the Student $t$-test $(\alpha=0.05$ ) between mean values ( $n=6$ plants) of $\mathrm{Al}$ treatments. Bars are s.e.

\section{Discussion}

\subsection{Water relations}

In the present study, we confirmed that leaf hydration of plants exposed to $\mathrm{Al}$ is considerably reduced, and it led to a lack of response of gs to the increase in VPD (Fig. 1C,D), which corroborates our hypothesis. Most studies about the effect of VPD on stomatal conductance $(g s)$ of unstressed plants have shown that $g s$ decreases with the increase in VPD (Monteith, 1995; Habermann et al., 2003; Peak and Mott, 2011; Aliniaeifard and van Meeeteren, 2013), which occurred in plants not exposed to $\mathrm{Al}$ and submitted to $2.5 \mathrm{kPa}$ (Fig. 1C). Leaves are believed to possess a feedback on leaf water content in order to stabilize leaf transpiration (E) (Sinclair and Allen, 1982), and an increase in VPD usually results in an increase in $E$ with an adjustment in $g s$ in order to match water flux from roots into the leaf (Sinclair et al., 2017). In plants

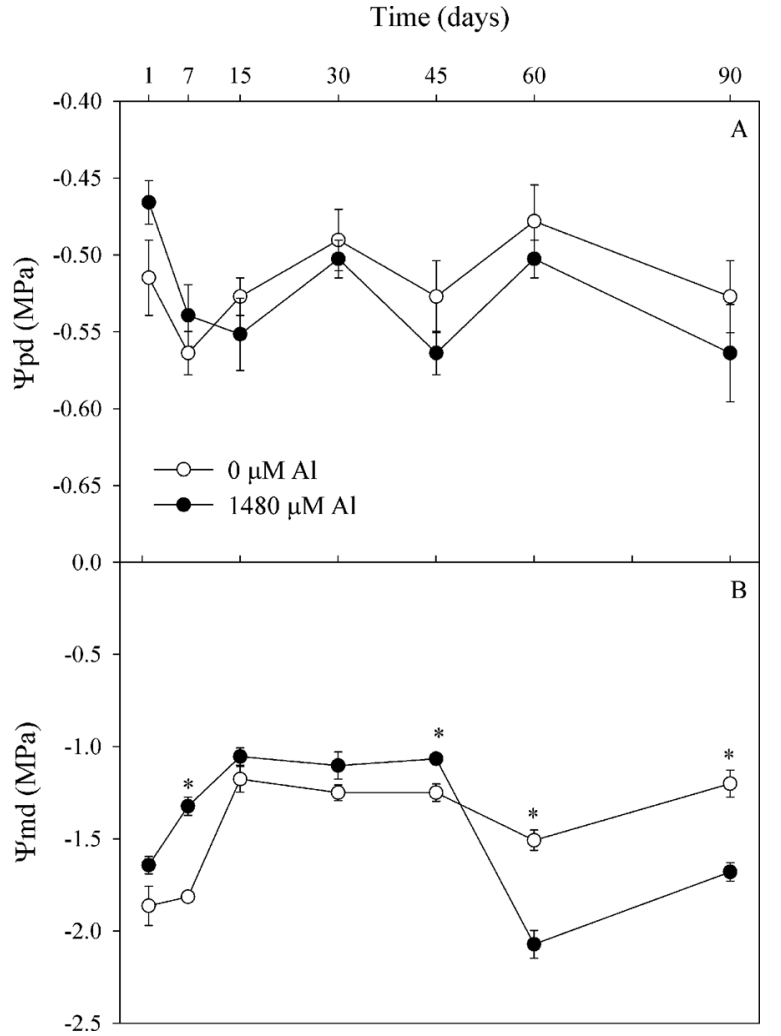

Fig. 6. Leaf water potential at predawn $\left(\Psi_{\mathrm{pd}}\right)(\mathrm{A})$ and midday $\left(\Psi_{\mathrm{md}}\right)(\mathrm{B})$ of 'Rangpur' lime plants cultivated for 90 days in nutrient solution containing 0 and $1480 \mu \mathrm{M}$ Al. For each evaluation date, asterisks indicate significant difference by the Student $t$-test $(\alpha=0.05$ ) between mean values ( $n=6$ plants) of Al treatments. Bars are s.e.

not exposed to $\mathrm{Al}$, the increase in VPD led to an increase in $E$ throughout the study (Fig. 1G), following the model proposed by most studies (Peak and Mott, 2011; Sinclair et al., 2017). In plants exposed to $\mathrm{Al}, E$ was higher under $2.5 \mathrm{kPa}$ when compared to $1.5 \mathrm{kPa}$, but only until 45 DAP, being unresponsive to the increase in VPD at 60 and 90 


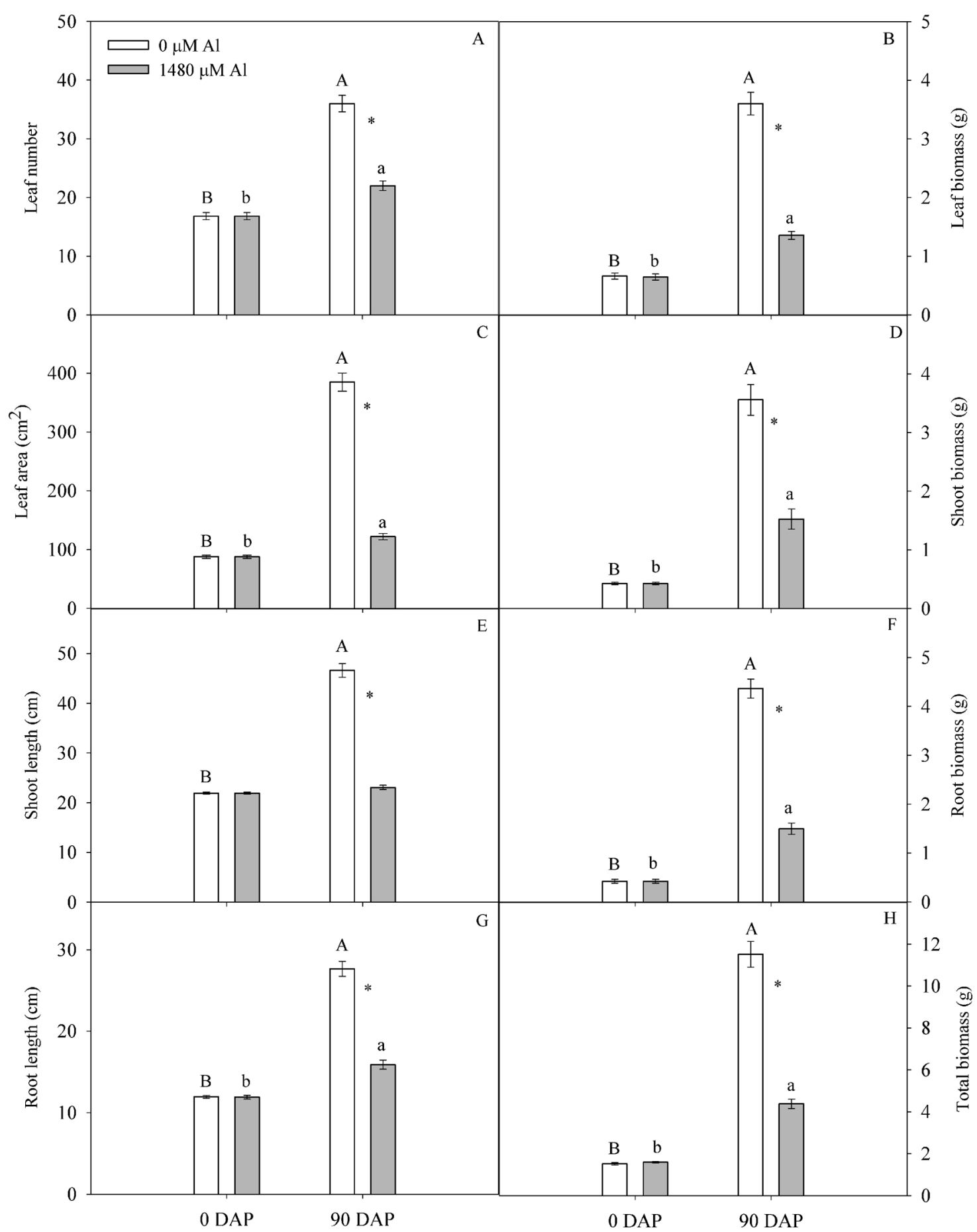

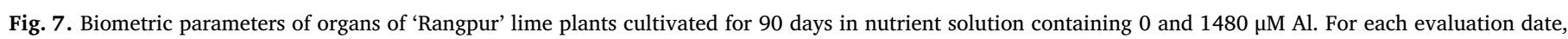

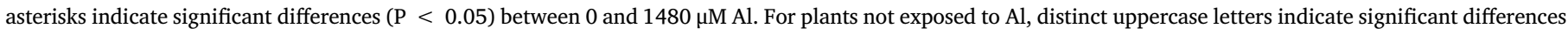

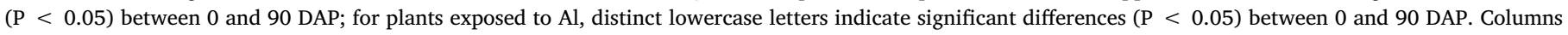
are mean values ( $n=6$ plants) and bars are s.e.

DAP (Fig. 1H). This matches the RWC and $\Psi \mathrm{md}$ responses that were significantly reduced at 60 and 90 DAP. This indicates that water supply to the mesophyll was considerably affected by the $\mathrm{Al}$ from 60 DAP.

Studies using 'Rangpur' lime plants (Pereira et al., 2000) and coffee plants (Konrad et al., 2005) reported lower values of WUE when these plants were exposed to 400 and $1480 \mu \mathrm{M} \mathrm{Al}$, respectively. In the present study, IWUE followed the $g s$ response pattern, either in plants exposed or not exposed to $\mathrm{Al}$ (Fig. 3C, D). WUE, however, was higher at $1.5 \mathrm{kPa}$ than $2.5 \mathrm{kPa}$ in plants not exposed to $\mathrm{Al}$ throughout the study (Fig. 3B).
In plants exposed to $\mathrm{Al}$, WUE became unresponsive to VPD at 60 and 90 DAP (Fig. 3B), as also occurred with $E$. This reinforces that in the presence of $\mathrm{Al}$ for more than 45 days the water supply to the mesophyll is significantly affected. Evidence of low leaf hydration in plants exposed to $\mathrm{Al}$ was already observed in a previous study, as $\Psi \mathrm{md}$ of 'Rangpur' lime plants exposed to $1480 \mu \mathrm{M}$ Al was 35\% lower when compared to plants not exposed to Al (Banhos et al., 2016). 


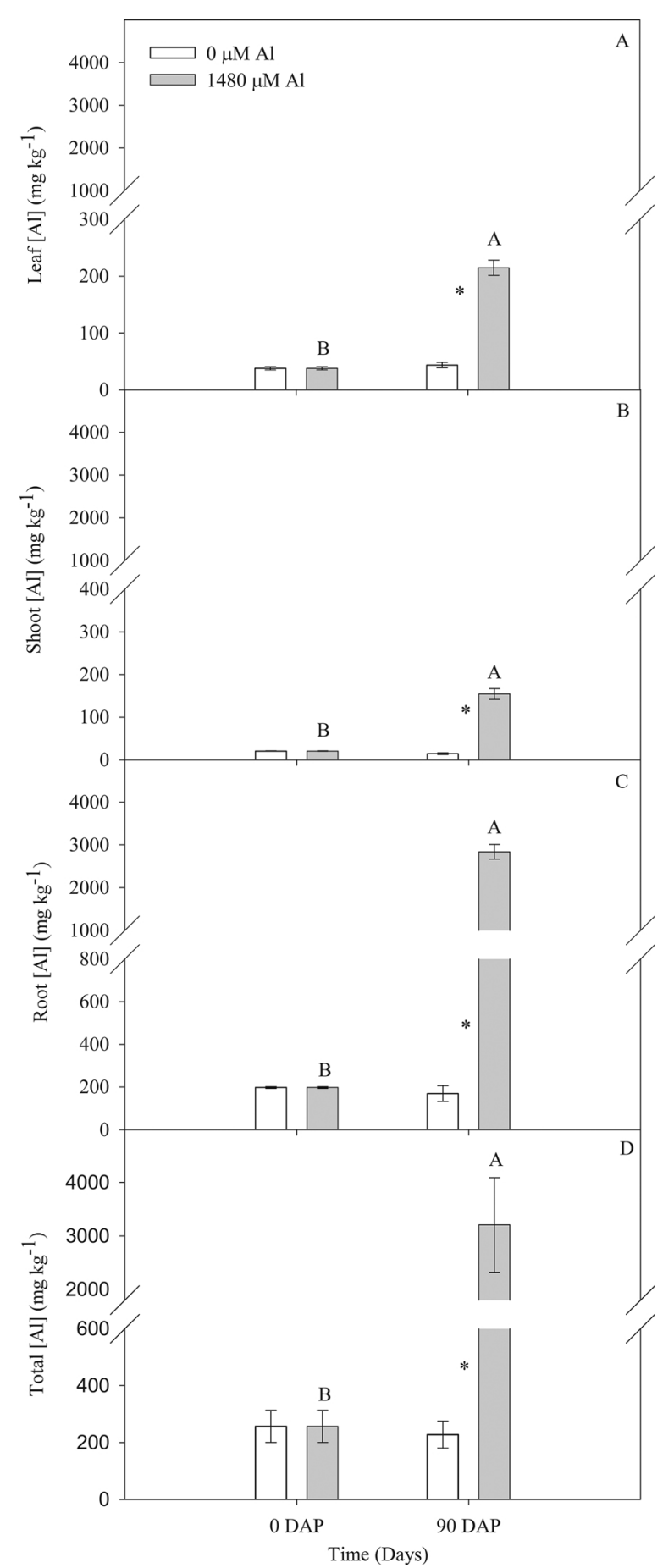

Fig. 8. Aluminum concentration in leaves (A), shoots (B), roots (C) and in the whole plant (D) of 'Rangpur' lime plants cultivated for 90 days in nutrient solution containing 0 and $1480 \mu \mathrm{M} \mathrm{Al}$. Asterisks represent significant differences $(\mathrm{P}<0.05)$ between 0 and $1480 \mu \mathrm{M} \mathrm{Al}$. For each treatment, distinct letters indicate significant differences $(\mathrm{P}<0.05)$ between 0 and 90 DAP. Columns are mean values ( $n=6$ plants) and bars are s.e.

\subsection{Photosynthetic parameters}

The $\mathrm{CO}_{2}$ assimilation rate $(A)$ followed the same response pattern exhibited by gs. In plants not exposed to $\mathrm{Al}, A$ decreased in response to the increase in VPD, which has been already noted for unstressed plants (Habermann et al., 2003; Chaves et al., 2016). In plants exposed to Al, $A$ was the same at 1.5 and $2.5 \mathrm{kPa}$ (Fig. $1 \mathrm{~A}, \mathrm{~B})$. These results indicate that $A$ was dependent on $g s$ in plants exposed to 0 and $1480 \mu \mathrm{M}$ Al. In studies using Citrus (Chen et al., 2005; Jiang et al., 2008, 2009) and coffee (Konrad et al., 2005) plants exposed to more than $1000 \mu \mathrm{M} \mathrm{Al}$, low $A$ and $g s$ values are also reported. However, these studies attribute the Alinduced decrease in $A$ to the low photochemical performance rather than the low gs. In plants exposed to $\mathrm{Al}, \mathbf{D}$ was higher and $\mathbf{P}$ was lower when compared to those not exposed to Al, corroborating the abovementioned studies, but $\mathbf{D}$ was the same between VPD, and $\Phi P S I I$ and ETR showed differences between VPD only at 1 and 60 DAP while qP was the same between VPD throughout the study (Supplementary material; Fig S1). Therefore, our results suggest that low gs and photochemical performance occur concomitantly in plants exposed to $\mathrm{Al}$ (being these parameters associated with the $\mathrm{Al}$ disturbance), or that low gs could lead to low photochemical responses in these plants, since Alinduced decrease in $g s$ was more consistent than the Al-induced decrease in photochemical responses. Plants of $C$. limonia grown in 1480 $\mu \mathrm{M} \mathrm{Al}$ do not show reduced photochemical responses until 45 days, while $g s$ is affected by Al within the same period (Banhos et al., 2016). Thus, it could also be a matter of time of $\mathrm{Al}$ exposure and/or a speciesdependent response. For instance, studies attributing the Al-induced decrease in $A$ to the low photochemical performance were conducted submitting 'Cleopatra' tangerine (Citrus reshni Hort. Ex. Tanaka) to Al for 60 days (Chen et al., 2005), Citrus grandis for 150 days (Jiang et al., 2008), C. grandis for 126 days (Jiang et al., 2009), and coffee plants (Coffea arabica) for 97 days (Konrad et al., 2005).

At 90 DAP, $\mathrm{Ci}$ was higher in plants exposed to $\mathrm{Al}$ regardless of the VPD, suggesting an impairment of Ribulose-1,5-bisphosphate carboxylase/oxygenase (Rubisco) enzyme activity. In fact, the estimation of the apparent carboxylation efficiency was higher in plants not exposed to $\mathrm{Al}$ in relation to those exposed to $\mathrm{Al}$. In vitro Rubisco activity was also lower in rye exposed to 1110 and $1850 \mu \mathrm{M} \mathrm{Al}$ after three weeks in relation to plants not exposed to Al (Silva et al., 2012), and in coffee plants the $\mathrm{A} / \mathrm{Ci}$ ratio (instantaneous carboxylation efficiency) was reduced in plants exposed to $1480 \mu \mathrm{M}$ Al for 97 days (Konrad et al., 2005). However, in the present study, the reduction of the angular coefficient of $\mathrm{A} / \mathrm{Ci}$ curve in plants exposed to $\mathrm{Al}$ did not occur at $2.5 \mathrm{kPa}$, indicating that stomatal responses may be, somehow, more important than biochemical responses, at $90 \mathrm{DAP}$, at least when changes in VPD are involved. Notwithstanding, $\mathrm{A} / \mathrm{Ci}$ curves were measured only at 90 DAP and accurate carboxylation efficiency measurements performed over the time of $\mathrm{Al}$ exposure merits further investigation in similar studies.

\subsection{Aluminum concentration in plant organs}

The present study reiterates that $\mathrm{Al}$ reduces leaf hydration in 'Rangpur' lime plants. As a novelty, we show that this effect leads to a lack of response of $g s$ to the increase in VPD. The possible causes of the Al-induced decrease in leaf hydration could be related to the impairment of water uptake by roots, where $\mathrm{Al}$ is mostly retained. For instance, $65 \%$ of the absorbed $\mathrm{Al}$ is immobilized in the roots of Citrus grandis and C. sinensis when exposed to $1200 \mu \mathrm{M} \mathrm{Al}$ (Yang et al., 2011) and $80 \%$ in the roots of Citrus limonia exposed to $1110 \mu \mathrm{M} \mathrm{Al}$ (Santos et al., 1999) and $1480 \mu \mathrm{M} \mathrm{Al}$ (Banhos et al., 2016). In the present study, $85 \%$ of the absorbed $\mathrm{Al}$ was retained in the roots (Fig. 8). Thus, the Al retained in the apoplast of root cells could impair the water flux, as evidenced by a marked reduction in flow rate on addition of $\mathrm{Al}$ to solution flowing through a calcium pectate membrane in an in vitro system (Blamey et al., 1993), although these results can be described as controversial (Horst et al., 2010). In fact, it has been identified that the first lesion of toxic $\mathrm{Al}$ is the binding of this metal to the pectic nets on walls of outer cells in the root system, reducing the root growth (Kopittke et al., 2015). Fibrous xylem vessels with structural modifications of the stele and reduced $\Psi$ md were already reported in 'Rangpur' lime plants exposed to $1480 \mu \mathrm{M}$ Al, suggesting a lack of functional capacity of the fibrous xylem vessels to transport water (Banhos et al., 2016). Therefore, sap flow rate measurements and gene 
expression of aquaporins are candidates for future investigations aiming at revealing the cause of reduced water uptake and transport, eventually explaining the low $g s$ and leaf hydration in plants exposed to Al.

\subsection{Plant growth}

One may still argue that the first and most conspicuous symptom of Al toxicity is the inhibition of the root growth (Kopittke et al., 2008; Horst et al., 2010), and that some studies (Vitorello et al., 2005; Kochian et al., 2015; Rengel et al., 2015) have supported that Al-induced decrease in root growth would lead to reduced water uptake, eventually explaining the Al-induced decrease in gs. However, compared to plants not exposed to $\mathrm{Al}$, plants exposed to $1480 \mu \mathrm{M} \mathrm{Al}$ showed reduced leaf number $(-40 \%)$, leaf area $(-75 \%)$, shoot length $(-60 \%)$, leaf biomass $(-57 \%)$ and shoot biomass (-60\%) observed at 90 DAP (Fig. 7), therefore compensating for the decrease in their root length $(-44 \%)$ and root biomass $(-65 \%)$, and reinforcing that a reduction of the intrinsic capacity of water uptake and transport could occur in plants exposed to Al.

\section{Conclusions}

In the present study, we confirm that leaf hydration of 'Rangpur' lime plants exposed to $\mathrm{Al}$ is considerably reduced, and it leads to a lack of response of $g s$ to the increase in VPD. The reduced photochemical responses observed in plants exposed to $\mathrm{Al}$ occurred concomitantly to low gs, but low photochemical responses were not as consistent as those related to stomatal control. In addition, the estimation of the apparent carboxylation efficiency was reduced in plants exposed to $\mathrm{Al}$, although under the highest VPD this biochemical reduction did not occur, reinforcing the importance of diffusive responses (stomatal control), which merits further investigation in plants exposed to Al.

\section{Author contributions}

Conceived and designed experiments: Habermann G, Silva GS Performed experiments: Silva GS, Gavassi MA, Nogueira MA

Analyzed data: Silva GS, Habermann G

Contributed to reagents/material/analytical tools: Habermann G

Wrote the manuscript: Silva GS, Habermann G, Gavassi MA

\section{Acknowledgements}

G. S. Silva acknowledges the Coordination for the Improvement of Higher Education Personnel (Capes) for a MSc. scholarship. M.A. Gavassi acknowledges the São Paulo Research Foundation (Fapesp) for a PhD scholarship (Fapesp \#2015/25409-4). G. Habermann acknowledges the Brazilian National Council for Scientific and Technological Development (CNPq) for a research productivity fellowship (Grant 309149/2017-7). We thank the Sanicitrus Nursery (Araras, São Paulo state, Brazil) for providing us with the 'Rangpur' lime plants.

\section{Appendix A. Supplementary data}

Supplementary material related to this article can be found, in the online version, at doi:https://doi.org/10.1016/j.envexpbot.2018.08. 017.

\section{References}

Ahmed, I.M., Nadira, U.A., Cao, F., He, X., Zhang, G., Wu, F., 2016. Physiological and molecular analysis on root growth associated with the tolerance to aluminum and drought individual and combined in Tibetan wild and cultivated barley. Planta 243, 973-985.

Aliniaeifard, S., van Meeeteren, U., 2013. Can prolonged exposure to low VPD disturb the ABA signalling in stomatal guards cells? J. Exp. Bot. 64, 3551-3566.
Baker, N.R., 2008. Chlorophyll fluorescence: a probe of photosynthesis in vivo. Ann. Rev. Plant Biol. 59, 89-113.

Banhos, O.F.A.A., Carvalho, B.M.O., Veiga, E.B., Bressan, A.C.G., Tanaka, F.A.O., Habermann, G., 2016. Aluminum-induced decrease in $\mathrm{CO}_{2}$ assimilation in 'Rangpur' lime is associated with low stomatal conductance rather than low photochemical performances. Sci. Hortic. 205, 133-140.

Bauer, H., Ache, P., Lautner, S., Fromm, J., Hartung, W., Al-Rasheid, K.A., Sonnewald, S., Sonnewald, U., Kneitz, S., Lachmann, N., 2013. The stomatal response to reduced relative humidity requires guard cell autonomous ABA synthesis. Curr. Biol. 23, 53-57.

Blamey, F.P.C., Asher, C.J., Edwards, D.C., Kerven, G.L., 1993. In vitro evidence of aluminum effects on solution movement through root cell walls. J. Plant Nutr. 16, $555-562$.

Chaves, M.M., Pereirea, J.S., Maroco, J., Rodrigues, M.L., Ricardo, C.P.P., Osório, M.L., Carvalho, I., Faria, T., Pinheiro, C., 2002. How plants cope with water stress in the field. Photosynthesis and growth. Ann. Bot. 89, 907-916.

Chaves, M.M., Costa, J.M., Zarrouk, O., Pinheiro, C., Lopes, C.M., Pereira, J.S., 2016. Cotrolling stomatal aperture in semi-arid regios - the dilemma of saving water or being cool? Plant Sci. 251, 54-64.

Chen, L.S., Qi, Y.P., Smith, B.R., Liu, X.H., 2005. Aluminum-induced decrease in CO2 assimilation in Citrus seedlings is unaccompanied by decreased activities of key enzymes involved in CO2 assimilation. Tree Physiol. 25, 317-324.

Clark, R.B., 1975. Characterization of phosphatase of intact maize roots. J. Agric. Food Chem. 23, 458-460.

Demming-Adams, B., 1996. Using chlorophyll fluorescence to assess the fraction of absorbed light allocated to thermal dissipation of excess excitation. Physiol. Plant. 98, 253-264.

Farquhar, G.D., Sharkey, T.D., 1982. Stomatal conductance and photosynthesis. Annu. Rev. Plant Physiol. 33, 317-345.

Habermann, G., Machado, E.C., Rodrigues, J.D., Medina, C., 2003. Gas exchange rates at different vapor pressure deficits and water relations of 'Pera' sweet orange plants with Citrus Variegated Chlorosis (CVC). Sci. Hortic. 98, 233-245.

Habermann, G., Ellsworth, P.F.V., Cazoto, J.L., Simão, E., Bieras, A.C., 2011. Comparative gas exchange performance during the wet season of three Brazilian Styrax species under habitat conditions of cerrado vegetation types differing in soil water availability and crown density. Flora 206, 351-359.

He, J., Li, H., Ma, C., Zhang, Y., Polle, A., Rennenberg, H., Cheng, Y.Q., Luo, Z.B., 2015. Overexpression of bacterial $\gamma$-glutamylcysteine synthetase mediates changes in cadmium influx, allocation and detoxification in poplar. New Phytol. 205, 240-254.

Horst, W.J., Wang, Y., Eticha, D., 2010. The role of the root apoplast in aluminiuminduced inhibition of root elongation and in aluminium resistance of plants: a review. Ann. Bot. 106, 187-197.

Jiang, H.-X., Chen, L.-S., Zheng, J.-G., Han, S., Tang, N., Smith, B.R., 2008. Aluminuminduced effects on photosystem II photochemistry in Citrus leaves assessed by the chlorophyll a fluorescence transient. Tree Physiol. 28, 1863-1871.

Jiang, H.-X., Tang, N., Zheng, J.-G., Li, Y., Chen, L.-S., 2009. Phosphorus alleviates aluminum-induced inhibition of growth and photosynthesis in Citrus grandis seedlings. Physiol. Plant. 137, 298-311.

Kissmann, C., da Veiga, E.B., Eichemberg, M.T., Habermann, G., 2014. Morphological effects of flooding on Styrax pohlii and the dynamics of physiological responses during flooding and post-flooding conditions. Aquat. Bot. 119, 7-14.

Kochian, L.V., Piñeros, M.A., Liu, J., Magalhaes, J.V., 2015. Plant adaptation to acid soil: the molecular basis for crop aluminium resistance. Annu. Rev. Plant Biol. 66, 571-598.

Konrad, M.L.F., Silva, J.A.B., Furlani, P.R., Machado, E.C., 2005. Trocas gasosas e fluorescência da clorofila em seis cultivares de cafeeiro sob estresse de aluminio. Bragantia 64, 339-347.

Kopittke, P.M., Blamey, F.P.C., Menzies, N.W., 2008. Toxicities of Al Cu, and La include ruptures to rhizodermal and root cortical cells of cowpea. Plant Soil 303, 217-227.

Kopittke, P.M., Moore, K.L., Lombi, E., Gianoncelli, A., Ferguson, B.J., Blamey, F.P.C., Menzies, N.W., Nicholson, T.M., McKenna, B.A., Wang, P., Gresshoff, P.M., Kourousias, G., Webb, R.I., Green, K., Tollenaere, A., 2015. Identification of the primary lesion of toxic aluminum in plant roots. Plant Physiol. 167, 1402-1411.

Kriedemann, P.E., Loveys, B.R., Fuller, G.L., Leopold, A.C., 1972. Abscisic acid and stomatal regulation. Plant Physiol. 49, 842-847.

Lange, O.L., Lösch, R., Schultze, E.D., Kappen, L., 1971. Responses of stomata to changes in humidity. Planta 100, 76-86.

Luo, Z.B., He, J., Polle, A., Rennenberg, H., 2016. Heavy metal accumulation and signal transduction in herbaceous and woody plants: paving the way for enhancing phytoremediation efficiency. Biotechnol. Adv. 34, 1131-1148.

Magalhães Filho, J.R., Amaral, L.R., Machado, D.F.S.P., Medina, C.L., Machado, E.C., 2008. Deficiência hídrica: trocas gasosas e crescimento de raízes em laranjeira 'Valência' sobre dois tipos de porta-enxerto. Bragantia 67, 75-82.

McAdam, S.A.M., Brodribb, T.J., 2015. The evolution of mechanisms driving the stomatal response to vapour pressure deficit. Plant Physiol. 167, 833-843.

Merilo, E., Jalakas, P., Kollist, H., Brosché, M., 2015. The role of ABA recycling and transporter proteins in rapid stomatal responses to reduced air humidity, elevated CO2, and exogenous ABA. Mol. Plant 8, 657-659.

Monteith, J.L., 1995. A reinterpretation of stomatal responses to humidity. Plant Cell Environ. 18, 357-364.

Mott, K.A., Peak, D., 2013. Testing a vapour-phase model of stomatal responses to humidity. Plant Cell Environ. 36, 936-944.

Peak, D., Mott, K.A., 2011. A new, vapour-phase mechanism for stomatal responses to humidity and temperature. Plant Cell Environ. 34, 162-178.

Pereira, W.E., Siqueira, D.L., Martinez, C.A., Puiatti, M., 2000. Gas exchange and chlorophyll fluorescence in four citrus rootstocks under aluminium stress. J. Plant Physiol. 
$157,513-520$.

Rengel, Z., Bose, J., Chen, Q., Tripathi, B.N., 2015. Magnesium alleviates plant toxicity of aluminium and heavy metals. Crop Pasture Sci. 66, 1298-1307.

Santos, C.H.S., Filho, H.G., Rodrigues, J.D., Pinho, S.Z., 1999. Níveis de alumínio e acúmulo de macronutrientes em porta-enxertos cítricos em cultivo hidropônico. Sci. Agric. 56, 1165-1175.

Sarruge, J.R., Haag, H.P., 1974. Análises Químicas Em Plantas. ESALQ (USP), Piracicaba. In Portuguese..

Schulze, E.D., 1986. Carbon dioxide and water vapour exchange in response to drought in the atmosphere and in the soil. Annu. Rev. Plant Physiol. 37, 247-274.

Shaff, J.E., Shultz, B.A., Craft, E.J., Clark, R.T., Kochian, L.V., 2010. GEOCHEM-EZ: achemical speciation program with greater power and flexibility. Plant Soil 330 207-214.

Sharp, R.E., Poroyko, V., Hejlek, L.G., Spollen, W.G., Springer, G.K., Bohnert, H.J., Nguyen, H.T., 2004. Root growth maintenance during water deficits: physiology to functional genomics. J. Exp. Bot. 55, 2343-2351.

Silva, S., Pinto, G., Dias, M.C., Correia, C.M., Moutinho-Pereira, J., Pinto-Carnide, O., Santos, C., 2012. Aluminium long-term stress differently affects photosynthesis in rye genotypes. Plant Physiol. Biochem. 54, 105-112.

Sinclair, T.R., Allen Jr., L.H., 1982. Carbon dioxide and water vapor exchange of leaves on field-grown citrus trees. J. Exp. Bot. 33, 1166-1175.

Sinclair, T.R., Devi, J., Shekoofa, A., Choudhary, S., Sadok, W., Vadez, V., Riar, M., Rufty, T., 2017. Plant Sci. 260, 109-118.

Turner, N.C., 1981. Techniques and experimental approaches for the measurement of plant water status. Plant Soil 58, 339-366.

Vitorello, V.A., Capaldi, F.R., Stefanuto, V.A., 2005. Recent advances in aluminium toxicity and resistance in higher plants. Braz. J. Plant Physiol. 17, 129-143.

von Uexküll, H.R., Mutert, E., 1995. Global extent, development and economic impact of acid soils. In: Date, R.A. (Ed.), Plant Soil Interactions at Low pH. Kluwer Academic Publishers, Dordrecht, pp. 5-19.

Xie, X., Wang, Y., Williamson, L., Holroyd, G.H., Tagliavia, C., Murchie, E., Teobald, J., Knight, M.R., Davies, W.J., Leyser, H.M., Hetherington, A.M., 2006. The identification of genes involved in the stomatal response to reduced atmospheric relative humidity. Curr. Biol. 16, 882-887.

Yang, L.-T., Jiang, H.-X., Tang, N., Chen, L.-S., 2011. Mechanisms of aluminum-tolerance in two species of Citrus: secretion of organic acid anion sand immobilization of aluminum by phosphorus in roots. Plant Sci. 180, 521-530.

Yang, Z.-B., Rao, I.M., Horst, W.J., 2013. Interaction of aluminium and drought stress on root growth and crop yield on acid soils. Plant Soil 372, 3-25. 